\title{
Kiusaamiskokemukset yhteisöön kiinnittymisen esteenä
}

\author{
Maili Pörhölä
}

Artikkeli perustuu Puheviestinnän päivillä 25.9.2009 pidettyyn plenum-esitelmään Kiusaamiskokemukset yhteisöön kiinnittymisen esteenä.

Tarkastelen tässä artikkelissa lyhyesti vertaissuhteiden kehityspolkuja lapsuudesta aikuisuuteen. Tutkimustuloksiin nojaten pohdin erityisesti sitä, miten kouluaikaiset kiusaamiskokemukset vaikuttavat yksilön henkiseen ja sosiaaliseen hyvinvointiin ja hänen kykyynsä kiinnittyä erilaisiin vertaisyhteisöihin kouluaikanaan ja myöhemmin elämässään. Kehittämäni vertaisyhteisöön kiinnittymisen teorian (Pörhölä 2009c) avulla pyrin havainnollistamaan erilaisten vertaissuhteiden ja erityisesti kiusaamissuhteiden merkitystä hyvinvoinnille sekä kiusaamisen uhrien että toisia kiusaavien vuorovaikutussuhteissa.

Vertaissuhteilla ja vertaisyhteisöillä on tärkeä merkitys yksilön henkiselle, fyysiselle ja sosiaaliselle hyvinvoinnille. Erilaiset opiskelu- ja työyhteisöt muodostuvat länsimaisissa kulttuureissa yleensä keskeisimmiksi ja pitkäkestoisimmiksi vertaisyhteisöiksi. Näiden yhteisöjen jäsenyyttä ja hyväksyntää tavoitellaan, ja niiden ulkopuolelle jääminen koetaan yleensä menetykseksi.

Opiskelu- ja työyhteisöjen ominaispiirteisiin kuuluu se, että niissä yksilöt ohjautuvat vertaissuhteisiinsa pääsemättä itse valitsemaan, kenen kanssa rakentavat opiskelutoveri- tai työtoverisuhdetta. Niinpä hyvien, palkitsevien vertaissuhteiden luominen ja ylläpitäminen saattavatkin joskus muodostua haasteeksi. Vertaissuhteet voivat muodostua jopa yksilön hyvinvointia ja kehitystä haittaaviksi tekijöiksi.

Tuoreimman kouluterveyskyselyn mukaan lukuvuonna 2006-2007 Suomessa peruskoulua suorittavista kahdeksas- ja yhdeksäsluokkalaisista pojista noin kymmenen prosenttia ja tytöistä kuusi prosenttia koki olevansa koulutovereidensa kiusaamisen ja syrjinnän kohteena vähintään kerran viikossa (Luopa, Pietikäinen \& Jokela 2008a). Joidenkin kohdalla kiusaaminen jatkuu vielä lukiossa tai ammatillisessa oppilaitoksessa (Luopa, Pietikäinen \& Jokela 2008b). Tuoreet tutkimustulokset osoittavat myös, että noin kuusi prosenttia suomalaisista korkeakouluopiskelijoista kokee olevansa opiskelutovereidensa säännöllisen kiusaamisen ja syrjinnän kohteena (Pörhölä 2009a). Lisäksi kiusaamista esiintyy työpaikoilla.

Vaikka kiusaamisen yleisyydestä saatuja tutkimustuloksia ei voida suoraan verrata toisiinsa tutkimusmenetelmiin liittyvien vaihtelevien ratkaisujen vuoksi, 
edellä kuvatut havainnot osoittavat kuitenkin sen, että kiusaamista esiintyy niin lasten, nuorten kuin aikuistenkin keskuudessa. Lisäksi havainnot nostavat esiin kysymyksiä kiusaamisen jatkumoista kontekstista toiseen. Päätyvätkö kouluaikanaan kiusaamisprosesseissa osallisina olleet oppilaat kiusaamisen kohteiksi tai kiusaamaan toisia myös siirtyessään vertaisyhteisöstä toiseen, esimerkiksi siirtyessään kouluasteelta toiselle tai pyrkiessään myöhemmin kiinnittymään työelämään? Millaisia vaikutuksia kiusaamisella on kiusattujen ja toisia kiusanneiden elämään, ja miten he onnistuvat kiinnittymään uusiin vertaisyhteisöihin myöhemmin elämässään?

Tutkimukset osoittavat, että sekä intensiivistä koulukiusaamista kokeneilla että koulutovereitaan kiusanneilla lapsilla ja nuorilla on monenlaisia vaikeuksia vertaissuhteissaan ja hyvinvoinnissaan (ks. esim. Hawker \& Boulton 2000). Henkisen ja fyysisen pahoinvoinnin kuten masentuneisuuden, ahdistuneisuuden, surullisuuden, itsetunnon menetyksen, univaikeuksien, syömishäiriöiden ja särkytilojen lisäksi kiusatuksi joutuminen vaurioittaa vakavasti lapsen ja nuoren vertaissuhteita. Lisäksi se heikentää hänen mahdollisuuksiaan kiinnittyä turvallisesti vertaisyhteisöönsä. Kiusaaminen näyttää kuitenkin olevan kohtalokasta myös toisia kiusaaville oppilaille. Näillä nuorilla on todettu samankaltaisia psykofyysisen pahoinvoinnin oireita (esim. masentuneisuutta ja itsetuhoisia ajatuksia) kuin kiusatuillakin. Lisäksi hekin kokevat vakavia ongelmia vertaissuhteissaan. (Tarkemmin esim. Pörhölä 2008; 2009c.)

Peruskoulun seitsemäs- ja kahdeksasluokkalaisilta kyselylomakkein keräämäni aineisto osoitti, että kiusaamisen kohteena olleilta oppilailta joko puuttuivat läheiset ystävät tai heitä oli hyvin vähän. He pelkäsivät menettävänsä vähäisetkin ystävänsä ja kaverinsa sekä kokivat, että vertaiset eivät arvosta heitä eivätkä pidä heistä. He eivät tunteneet kuuluvansa luokkayhteisöönsä, kokivat vertaisiin tutustumisen vaikeaksi ja tunsivat jopa pelkoa ja epäluottamusta vertaisiaan kohtaan. Sekä kiusatun että kiusaajan roolissa vaihdellen toimivilla oppilailla, niin kutsutuilla kiusaaja-uhreilla, oli vertaissuhteissaan hyvin samankaltaisia ongelmia kuin kiusatuillakin oppilailla. Luonteenomaista tälle ryhmälle oli vertaissuhteissa koettu epävarmuus, kavereiden menettämisen pelko ja yleinen epäluottamus vertaisia kohtaan.

Tutkimus osoitti lisäksi sen, että vaikka toisia kiusanneilla oppilailla oli ystäviä ja kavereita, hekin pelkäsivät näiden menettämistä. Kiusattujen oppilaiden tavoin he tunsivat myös pelkoa ja epäluottamusta vertaisiaan kohtaan eivätkä tunteneet kuuluvansa luokkayhteisöönsä. Tyypillinen kehityskaari toisia kiusanneiden oppilaiden vertaissuhteissa näyttikin olevan se, että he kokosivat ympärilleen turvalliselta tuntuvan kaveriporukan, mutta eivät onnistuneet kiinnittymään laajempaan sidosryhmäänsä eli omaan luokkayhteisöönsä. (Ks. tarkemmin Pörhölä 2008.)

Kiusaamisella näyttää olevan seurauksia myös kiusattujen ja toisia kiusanneiden oppilaiden vuorovaikutussuhteisiin ja hyvinvointiin myöhemmin 
elämässä. Kiusattujen oppilaiden kehityspoluista tiedetään muun muassa, että vielä nuorina aikuisinakin he kärsivät muita enemmän yksinäisyydestä ja heidän on vaikea ylläpitää ystävyyssuhteitaan (Schäfer ym. 2004); heillä on kielteinen käsitys vertaistensa luotettavuudesta, ystävällisyydestä ja tuesta (Salmivalli \& Isaacs 2005); he kokevat luottamuksen puutetta ystävyyssuhteissaan ja ovat tyytymättömiä vuorovaikutussuhteidensa laatuun (Jantzer, Hoover \& Narloch 2006; Pörhölä 2006). Lisäksi koulukiusatuilla on muita suurempi riski päätyä kiusatuiksi myös korkeakouluopintojensa aikana (Pörhölä 2009b) sekä myöhemmin siirtyessään työelämään (Smith, Singer, Hoel \& Cooper 2003). Myös kouluampumisten taustalta on todennäköistä useammin löytynyt kiusaamiskokemuksia, vaikka tapausten suhteellisen pienen määrän perusteella ei voida vielä tehdä luotettavia johtopäätöksiä.

Toisia kiusanneiden oppilaiden kehityspolut poikkeavat kiusattujen kehityspoluista. Toisia kiusanneet näyttävät usein päätyvän toimimaan lähellään olevia ihmisiä, yhteisöään tai yhteiskuntaa jollain tavoin vahingoittavasti. Tämä näkyy esimerkiksi väkivaltaisuutena teini-iän seurustelusuhteissa sekä vertaisten sukupuolisena häirintänä (Connolly, Pepler, Craig \& Taradash 2000; Pepler, Craig, Connolly \& Henderson 2002), päihteiden väärinkäyttönä ja rikollisuutena (Kaltiala-Heino, Rimpelä, Rantanen \& Rimpelä 2000; Pepler ym. 2002; Sourander ym. 2007), miehillä antisosiaalisina persoonallisuushäiriöinä armeijaiässä (Sourander ym. 2007) sekä lisääntyneenä riskinä päätyä kiusaamaan opiskelutovereitaan korkeakouluopintojensa aikana (Pörhölä 2009b). Lisäksi on todettu, että kouluaikanaan toisia kiusanneiden miesten lapset päätyvät muita useammin kiusaamaan omia oppilastovereitaan (Farrington 1993).

Toisaalta tiedetään, että ystävät voivat suojata kiusaamisen uhria kiusaamisen kielteisiltä vaikutuksilta (esim. Hodges, Boivin, Vitaro \& Bukowski 1999). Ystävät voivat vahvistaa kiusatun itsetuntoa ja auttaa häntä näkemään itsensä arvostettuna ja pidettynä ihmisenä. Lisäksi ystävien olemassaolo tuo kiusatulle oppilaalle mahdollisuuksia harjaannuttaa vuorovaikutustaitojaan turvallisessa ympäristössä ja positiivista palautetta saaden.

\section{Vertaisyhteisöön kiinnittymisen teoria}

Kiusaamisen vaikutuksia käsitteleviin tutkimustuloksiin nojaten olen kehittänyt vertaisyhteisöön kiinnittymisen teorian (ks. Pörhölä 2009c). Teorian lähtökohtana on oletus, että yksilö kiinnittyy vertaisyhteisöönsä vuorovaikutussuhteidensa kautta. Siten hänen jokaisella vertaissuhteellaan on merkitystä sille, miten hyvin hän onnistuu kiinnittymään vertaisyhteisöönsä. Vertaissuhteilla tarkoitan niitä vuorovaikutussuhteita, joita lapsella tai nuorella on itsensä kanssa suunnilleen samanikäisten ja samalla kehitystasolla olevien kanssa. Vertaisyhteisöllä tarkoitan tässä teoriassa niiden vertaisten joukkoa, joiden kanssa lapsella tai nuorella on tai voisi olla vuorovaikutussuhde. Vertaisyhteisö kattaa siten suu- 
remman vertaisten joukon kuin vain sen vertaisryhmän, jonka jäsenet lapsi tai nuori jo tuntee.

Onnistuneesta vertaisyhteisöön kiinnittymisestä kertoo se, että lapsi tai nuori tuntee olevansa hyväksytty, pidetty ja arvostettu vertaistensa keskuudessa ja osoittaa itse hyväksyntää, välittämistä ja arvostusta vertaisiaan kohtaan. Tämän vastavuoroisen vuorovaikutusprosessin seurauksena hän tuntee itsensä vertaisyhteisönsä tasavertaiseksi jäseneksi.

Vertaisyhteisöön kiinnittymisen teoriassa luokittelen lapsen tai nuoren vertaissuhteet viidentyyppisiksi suhteen palkitsevuuden tai vahingollisuuden mukaan:

1) Ystävyyssuhteita leimaa molemminpuolinen läheisyyden, yhteenkuuluvuuden, arvostuksen ja hyväksytyksi tulemisen tunne, vastavuoroinen itsestä kertominen, toisen ymmärtäminen ja toisesta huolehtiminen, kiintymys, luottamus, tuki ja sitoutuminen.

2) Kaverisuhteissa osoitetaan keskinäistä hyväksyntää ja vietetään runsaasti aikaa yhteisten aktiviteettien parissa.

3) Neutraaleille vertaissuhteille on ominaista vastavuoroinen kiinnostuksen puute toista osapuolta kohtaan.

4) Vihollissuhteissa tyypillisiä piirteitä ovat vastavuoroiset kielteiset tunteet ja molemminpuolinen fyysinen tai verbaalinen loukkaaminen toistuvissa riidoissa ja konflikteissa.

5) Alistaville vertaissuhteille on ominaista yksipuolinen kiusaaminen, loukkaaminen, alistaminen ja syrjiminen ilman, että toinen osapuoli pystyy puolustautumaan tai vaikuttamaan saamaansa kohteluun. Kiusaamissuhde on tyypillinen esimerkki alistavasta vertaissuhteesta.

Vertaisyhteisöön kiinnittymisen teoriassa oletetaan, että ystävyys- ja kaverisuhteilla on myönteisin vaikutus yksilön kehitykselle. Ne auttavat häntä arvostamaan itseään, toisia ja vuorovaikutussuhteita sekä oppimaan tärkeitä vuorovaikutustaitoja. Ne myös lisäävät turvallisuuden ja elämänhallinnan tunnetta. Neutraaleilla vertaissuhteilla ei oleteta olevan sen enempää myönteistä kuin kielteistäkään merkitystä yksilön kehitykselle. Vihollissuhteilla on selvästi kielteinen vaikutus yksilölle, ja kaikkein tuhoisimpia ovat alistavat vertaissuhteet, joissa vallitsee vallankäytön epätasapaino.

Teoriassa oletetaan myös, että ystävyys- ja kaverisuhteet ikään kuin vetävät lasta tai nuorta kohti vertaisyhteisön keskiötä muodostaen eräänlaisen turvaverkon hänen ympärilleen. Sen sijaan vihollissuhteet ja alistavat vertaissuhteet työntävät lasta tai nuorta pois vertaisyhteisön keskiöstä, ajaen häntä vertaisten toisilleen muodostaman turvaverkon ulkopuolelle.

Sekä kiusattujen että toisia kiusaavien oppilaiden vertaissuhteille on ominaista, että niihin kuuluu useita alistavia vertaissuhteita ja ehkä myös joitakin vihollissuhteita. Koulukiusatulla oppilaalla voi olla samanaikaisesti monia alistavia vertaissuhteita ilman, että hänellä olisi yhtään ystävyys- tai kaverisuhdetta. 
Toisia kiusaavilla oppilailla puolestaan näyttää useimmiten olevan myös ystävyys- ja kaverisuhteita, vaikka heidänkin vertaissuhteitaan leimaavat alistavat suhteet, joissa he itse toimivat alistajina.

Vertaisyhteisöön kiinnittymisen teoriassa oletetaan lisäksi, että se miten yksilö onnistuu lapsuudessaan ja nuoruudessaan kiinnittymään vertaisyhteisöönsä, heijastuu siihen, miten hän onnistuu kiinnittymään uusiin vertaisyhteisöihin myöhemmin elämässään siirtyessään opiskeluasteelta toiselle ja lopulta siirtyessään työelämään. Vertaisyhteisöön kiinnittymisen teoria tuo esiin myönteisten, palkitsevien vuorovaikutussuhteiden merkityksen yksilön hyvinvoinnille ja sosiaaliselle kehitykselle. Ystävyys- ja kaverisuhteilla on erityisen tärkeä merkitys lapselle tai nuorelle, joka on osallisena vakavissa kiusaamisprosesseissa. Silloin, kun lapsi tai nuori ei kiusaamisen vuoksi onnistu kiinnittymään koulutovereidensa muodostamaan vertaisryhmään, turvallisia ystäviä ja kavereita olisi hyvä etsiä jostain toisesta vertaisryhmästä, vaikkapa harrastusten kautta tai naapureiden ja sukulaisten joukosta. Tällaiset ystävät voisivat paikata sitä turvaverkkoa, jonka laidalle oppilas on kouluyhteisössään sysätty, ja auttaa häntä kuitenkin kiinnittymään laajempaan vertaisyhteisöönsä. Vertaisyhteisöön kiinnittymisen teoriaa voitaneen soveltaa myös työelämän vuorovaikutussuhteiden tarkasteluun, vaikka sen lähtökohtana ovat olleet lapsuus- ja nuoruusajan vertaissuhteet.

\section{Kirjallisuus}

Connolly, J., Pepler, D., Craig, W. \& Taradash, A. 2000. Dating experiences of bullies in early adolescence. Child Maltreatment 5, 299-310.

Farrington, D. P. 1993. Understanding and preventing bullying. Teoksessa M. Tonry (toim.) Crime and Justice vol. 17. Chicago: University of Chicago Press, 381-458.

Hawker, D. S. J. \& Boulton, M. J. 2000. Twenty years' research on peer victimization and psychosocial maladjustment: A meta-analytic review of cross-sectional studies. Journal of Child Psychology and Psychiatry and Allied Disciplines 41, 441-455.

Hodges, E. V. E., Boivin, M., Vitaro, F. \& Bukowski, W. M. 1999. The power of friendship: Protection against an escalating cycle of peer victimization. Developmental Psychology 35, 94-101.

Jantzer, A. M., Hoover, J. H. \& Narloch, R. 2006. The relationship between school-aged bullying and trust, shyness and quality of friendships in young adulthood: A preliminary research note. School Psychology International 27, 146-156.

Kaltiala-Heino, R., Rimpelä, M., Rantanen, P. \& Rimpelä, A. 2000. Bullying at school - an indicator of adolescents at risk for mental disorders. Journal of Adolescence 23, 661-674. 
Luopa, P., Pietikäinen, M. \& Jokela, J. 2008a. Koulukiusaaminen peruskoulun yläluokilla 2000-2007. Opetusministeriön julkaisuja 7. Helsinki: Opetusministeriö.

Luopa, P, Pietikäinen, M. \& Jokela, J. 2008b. Kouluterveyskysely 1998-2007: Nuorten hyvinvoinnin kehitys ja alueelliset erot. Raportteja 23. Helsinki: Stakes.

Pepler, D., Craig, W., Connolly, J. \& Henderson, K. 2002. Bullying, sexual harassment, dating violence, and substance use among adolescents. Teoksessa C. Wekerle \& A. M. Wall (toim.) The violence and addiction equation: Theoretical and clinical issues in substance abuse and relationship violence. New York: Brunner-Routledge,153-168.

Pörhölä, M. 2006. Relational implications of school bullying: Developmental pathways in victims' interpersonal relationships. Paper presented at the International Association for Relationship Research convention, July, Rethymnon, Crete.

Pörhölä, M. 2008. Koulukiusaaminen nuoren hyvinvointia uhkaavana tekijänä. Miten käy kiusatun ja kiusaajan vertaissuhteille? Teoksessa M. Autio, K. Eräranta \& S. Myllyniemi (toim.) Polarisoituva nuoruus? Nuorten elinolot -vuosikirja 2008. Helsinki: Nuorisotutkimusverkosto/ Nuorisotutkimusseura, Julkaisuja 84, 94-104, Nuorisoasiain neuvottelukunta \& Sosiaali- ja terveysalan tutkimus- ja kehittämiskeskus Stakes.

Pörhölä, M. 2009a. Kiusaaminen opiskeluyhteisöissä: ongelman yleisyys, ehkäiseminen ja selvitteleminen. Tekeillä oleva käsikirjoitus.

Pörhölä, M. 2009b. Kouluaikaisten kiusaamiskokemusten vaikutus nuoren aikuisen hyvinvointiin ja ihmissuhteisiin. Tekeillä oleva käsikirjoitus.

Pörhölä, M. 2009c. Psychosocial well-being of victimized students. Teoksessa T. A. Kinney \& M. Pörhölä (toim.) Anti and pro-social communication: Theories, methods, and applications. Language as Social Action vol. 6, New York: Peter Lang, 83-93.

Salmivalli, C. \& Isaacs, J. 2005. Prospective relations among victimization, rejection, friendlessness, and children's self- and peer-perceptions. Child Development 76, 1161-1171.

Schäfer, M., Korn, S., Smith, P. K., Hunter, S. C., Mora-Merchán, J. A., Singer, M. M. \& van der Meulen, K. 2004. Lonely in the crowd: Recollections of bullying. British Journal of Developmental Psychology 22, 379-394.

Smith, P. K., Singer, M., Hoel, H. \& Cooper, C. L. 2003. Victimization in the school and the workplace: Are there any links? British Journal of Psychology 94, 175-188.

Sourander, A., Jensen, P., Rönning, J., Niemelä, S., Helenius, H., Sillanmäki, L., ym. 2007. What is the early adulthood outcome of boys who bully or are bullied in childhood? The Finnish "From a boy to a man" study. Pediatrics 120 (2), 397-404. 